Білецька Олена

здобувачка ступеня $\mathrm{PhD}$ кафедри вікової та педагогічної психології Рівненського державного гуманітарного університету, викладачка Сарненського педагогічного коледжу РДГУ https://orcid.org/ 0000-0002-9447-4455

DOI https://doi.org/10.35619/praprv.v1i16.210

\title{
ЕГОЦЕНТРИЗМ ЯК ЧИННИК НИЗЬКОГО РІВНЯ ДОВІРИ В КОНТЕКСТІ МІЖОСОБИСТІСНИХ СТОСУНКІВ У ПЕРІОД РАННЬОЇ ЮНОСТІ
}

Анотація. Стаття присвячена теоретичному обгрунтуванню та емпіричному розгляду проблеми егоцентризму, який зумовлює низький рівень довіри у осіб юнацького (студентського) віку. Встановлено, що егочентрична спрямованість детермінується позицією $і$ сприяє автономізаиії особистості від інших людей. Вона викликається потребами у власному успіху, в співчутті, в опіці, в афіліації, в самоствердженні, в захисті свого «Я». Егоцентризм відбивається на міжособистісних стосунках, перешкоджає ефективному спілкуванню і взаємодї з людьми, гальмує розвиток морально-етичної сфери особистості. Регулячія соціальної поведінки і життєдіяльності індивіда безпосередньо залежить від особливостей взаємодї людини з іншими людьми. Особистісний чинник виявляється провідним у всіх видах взаємостосунків людей один з одним, причому міжособистісні відносини відіграють особливо важливу роль.

На підставі результатів діагностики, було виявлено переважну більшість осіб (92\%) з низьким рівнем довіри в міжособистісних стосунках, у яких були досліджені такі соціально-психологічні характеристики, як рівень егочентризму та рівень емпатичних здібностей. Результати емпіричного дослідження вказують на надміру сконцентрованість юнаків $i$ дівчат на собі $i$ свойх власних думках, переживаннях, не здатності адекватно сприймати іншого учасника взаємодії, щзо проявляється в бракові співчуття до співрозмовника, у відсутності координаиї дій з партнером. Отримані результати стали психологічною основою для розробки сочіально-психологічного тренінгу, як ефективного засобу підвищення рівня довіри студентів та подолання «егоцентричної сліпоти» у період ранньої юності.

Ключові слова: рання юність, міжособистісні стосунки, довірливі стосунки, довіра, емпатія, егочентризм.

Постановка проблеми. Людина, як істота соціальна, протягом життя виступає як активний суб'єкт численної кількості міжособистісних контактів. Однак, часи штучного інтелекту та популяризації цифрових технологій у спілкуванні між людьми, змушують науковців подивитися на проблему безпосередньої міжособистісної взаємодії з іншого боку. За таких умов, одним із пріоритетних напрямів наукового пошуку постає дослідження соціальної контактності особистості, виявлення трансформацій, яких зазнала іï система міжособистісних стосунків, встановлення місця Іншого у житті людини, пошук ефективних механізмів формування та розвитку міжособистісних взаємин на засадах гуманізму, толерантності та взаєморозуміння. У цьому контексті науковий інтерес викликає дослідження егоцентризму в період ранньої юності як фактора, що ускладнює процес довірчих міжособистісних взаємин.

Актуальність дослідження феномену егоцентризму в ранньому юнацькому віці полягає у зростаючих вимогах суспільства до посилення соціалізації підростаючого покоління, здатності включатися в міжособистісні стосунки, брати відповідальність за себе та партнера по спілкуванню, не виключаючи при цьому самостійності та автономності підростаючої особистості. 
Аналіз останніх досліджень і публікацій. Проблема егоцентризму як деструктиву довірчого ставлення до інших людей стала предметом наукового дослідження багатьох учених (Пашукова, 2001; Анненкова, Антоненко, 2004; Сфремкіна, 2019).

Однак, комплексного експериментального дослідження взаємовпливу юнацького егоцентризму, емпатії та довіри у спілкуванні не проводилося. Відомо, що у цей же період значною мірою розширюється коло міжособистісних контактів, змінюються їх форми та види, спрямованість і значущість, набувають змін якісні характеристики. Усі ці трансформації надають взаєминам ще більшої гостроти, отже, роблять юнацький вік найбільш сприятливим для дослідження впливу егоцентризму, емпатії на формування, розвиток та особливості довірчої міжособистісної взаємодії.

Формулювання цілей статті. Метою нашої роботи $\epsilon$ дослідити феномен егоцентризму, особливості його прояву в формуванні міжособистісних стосунків у юнацькому віці; сформулювати власну точку зору з порушеної проблематики; визначити взаємовплив егоцентризму, емпатії та довіри у побудові міжособистісних стосунків в період ранньої юності.

Виклад основного матеріалу дослідження. Рання юність (15-17 років) надзвичайно суперечлива, складна і визначна стадія життєвого циклу, відмінними рисами якої $є$ відкритість та самоусвідомлення, сприйняття самоцінності своєї особистості та самопідтримка, зростання впевненості в собі та посилення автономності. Оптимальним статусом представників цього віку є студентство (за умов успішної адаптації до вузівського навчання та правильного вибору майбутньої професії) - юнаки-студенти отримують загальну та професійну освіту, шліфують свій інтелект, накопичують комунікативний досвід. Паралельно, з набуттям соціальної зрілості, в юнацькому віці спостерігається висока гнучкість соціальних ролей - представники цього періоду прилаштовуються до людей різних статусів, статі та віку.

На думку Барцалкіної (2004), «феномен самовизначення як усвідомлений акт виникає в онтогенезі лише на етапі ранньої юності, разом зі здібністю критично ставитись до себе, стати по відношенню до себе в позицію внутрішнього «іншого», що допомагає зрозуміти себе (с. 23). Саморозуміння та саморефлексія розвиваються і під впливом однолітків, які допомагають один одному в спілкуванні розкрити власне внутрішнє Я, подивитися на себе зі сторони іншої людини. Тому юнацька дружба виступає провідною потребою в прихильності та розвитку саморозуміння: «В основі юнацького потягу до дружби - потреба в розумінні іншого та себе іншим та в саморозкритті» (Анненкова, 2004, с. 149). Завдання розвитку «Я» в ранній юності передбачають незалежність в плануванні власного часу і прийняття рішень, зростання довіри до себе, посилення стійкості до фрустрацій, поглиблення самооцінки та самоповаги, підвищення вимогливості до себе та побудова реалістичних планів на майбутнє (Анненкова, 2004, с. 5). Водночас, має місце міжособистісне експериментування у спілкуванні, що сприяє накопиченню комунікативного досвіду юнаків, але й викликає певні розчарування. Залишається актуальним прагнення хлопців та дівчат перебувати у референтній групі, займати вагомий статус серед ровесників, що започаткувалось ще в підлітковому віці.

Підлітковий і юнацький вік є вирішальними у формуванні та розвитку особистості. Невирішені проблеми в самоствердженні та визнанні ведуть до посилення центрованості людини на собі. Для юнацької комунікативності, як і підліткової, теж $є$ характерним егоцентризм, так як потреба у самовираженні сильніша від інтересу до співрозмовника. Центр психічного життя особистості зміщується до власного Его. Егоцентризм криється в особливостях структури особистості: в її самооцінці, рівні домагань і потребах, мотивах і потягах, що має відношення до регуляції соціальної поведінки й життєдіяльності індивіда. Порушення в функціонуванні цієї структури породжує безліч проблем в житті особистості, 3 вирішенням яких стикається психолог (теоретик і практик) в своїй роботі. Феномен егоцентризму $є$ викривленням образу світу, відношення до нього тільки через власні, індивідуальні критерії оцінювання, які заважають адекватно сприймати і аналізувати точки зору інших. В свою чергу, це негативно впливає на міжособистісні стосунки, пізнання явищ

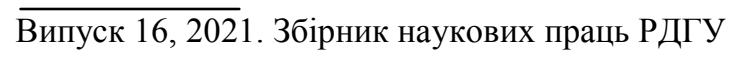


зовнішнього світу тобто загальну соціально-психологічну адаптацію, що, 3 огляду на суспільну природу людини, є вельми важливим для нормального розвитку і функціонування особистості. Вивчення цього феномена набуває неабиякого теоретичного і практичного значення, оскільки торкається фундаментальних основ особистості, уявлення про себе, на базі якого людина будує світогляд i, як наслідок, взаємодію зі світом та іншими людьми. Баланс зовнішнього і внутрішнього, розумне врахування власних та чужих інтересів, вірогідно, і $є$ ключовим компонентом в створенні гармонії існування особистості.

У вітчизняній психології егоцентризм пояснювався впливом соціальних умов на психіку людини. Наприклад, на його формування і розвиток можуть впливати неправильне виховання, низький рівень моральної культури, нерозвинені комунікативні здібності або несприятливі, кризові умови існування. На деструктивності цього феномена наголошували численні дослідники: одним з перших був Фрідман. В своїх експериментах на дорослій вибірці досліджуваних, яким давалося завдання пояснити дорогу товаришеві по телефону, він довів, що егоцентризм - це атрибут не тільки дитячого мислення, оскільки деякі дорослі люди теж можуть мати високий рівень егоцентризму ((2001, с. 15). На жаль, нам невідомі дослідження, які б розкривали проблему зв'язку різних форм егоцентризму. Більш сучасним, поширеним сьогодні в психологічній науці $є$ трактування егоцентризму як динамічного та ситуативного явища, яке актуалізується в певні періоди життя. Це положення і було покладене в основу нашого дослідження, основною гіпотезою якого є припущення, що високий рівень егоцентризму у юнацькому віці впливає на емпатію та рівень довіри у міжособистісних стосунках.

Об'сктом дослідження виступають особливості міжособистісних стосунків у осіб юнацького віку з різним рівнем довіри та емпатії; предметом - егоцентризм як феномен міжособистісних стосунків.

Емпіричне дослідження проводилося у 2021 році на базі ВСП «Сарненського педагогічного фахового коледжу Рівненського державного гуманітарного університету». У дослідженні брали участь студенти 1 - 3 курсів у віці 15 - 17 (60 осіб).

Для встановлення характеру зв'язку рівня розвитку егоцентризму особистості 3 міжособистісними стосунками у період юнацтва нами було обрано такі методики: «Шкала довіри» (Розенберг); «Діагностика рівня емпатичних здібностей» (Бойко); «Тест егоцентричних асоціацій» (Сцутрова). Дослідження складалося з трьох етапів. На першому етапі була проведена діагностика рівня довіри в міжособистісних стосунках за допомогою шкали довіри Розенберга, яка оцінює загальну довіру до людей і людської спільноти в цілому.

Аналіз та узагальнення результатів дослідження за методикою шкали довіри Розенберга дозволили визначити наступні показники рівнів довіри студентів періоду ранньої юності до інших людей. Кількісні результати дослідження відображено у діаграмі (рис. 1).

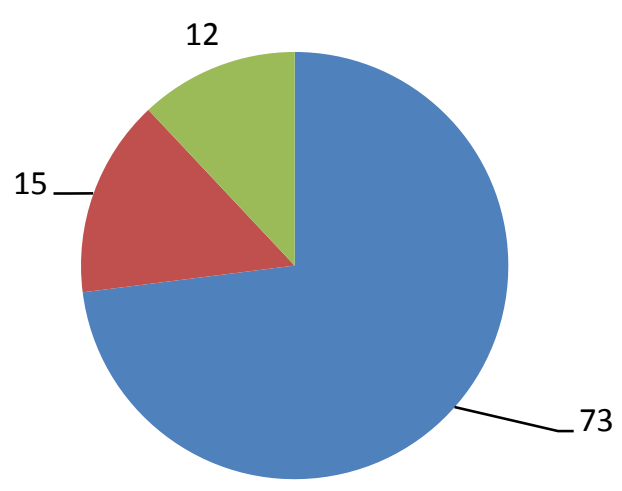

— занижений рівень

в високий рівень

передній рівень

Рис. 1. Рівень довіри до інших людей у період ранньої юності 
Результати дослідження показали, що більшість (92\%) студентів виявляють низький рівень довіри до інших людей. Середній (5 \%) та високий $(3 \%)$ рівні довіри до інших людей проявляе незначна частина студентів. Отримані результати вказують на залежність особистості у прийнятті рішення довіряти чи ні від думки інших людей, постійний пошук підтвердження правильності свого вибору, невпевненість у власних можливостях.

Виявлення механізмів та характеру зв'язку емпатії та довіри у міжособистісних стосунках розглядається на матеріалі діагностики рівня емпатичних здібностей за методикою Бойко, що стало другим етапом дослідження. Аналіз та узагальнення результатів дослідження за даною методикою представлено у діаграмі 2.

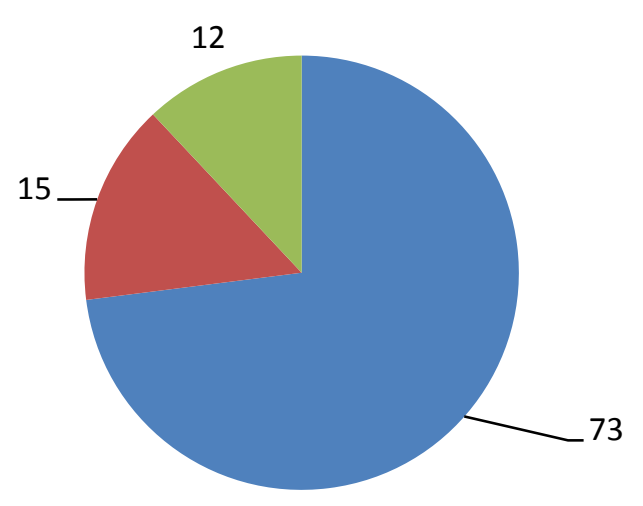

ванижений рівень

високий рівень

середній рівень

\section{Рис. 2. Рівень емпатї̈ до інших людей у період ранньої юності}

Занижений рівень емпатії (73\%) засвідчує факт недостатньої іï сформованості, не вмінням проникати у світ почуттів інших. Отже, взаємозв'язок особливостей розвитку емпатії особистості та міжособистісних стосунків юнаків безперечно існує. Чим більше особистість вміє співпереживати, ставити себе на місце співрозмовнка, тим легше їй буде встановлювати контакти з оточуючими людьми.

На третьому етапі дослідження було проведено тест егоцентричних асоціацій, що дало змогу виявити рівень егоцентричного спрямування у юнацькому віці. Кількісні результати дослідження відображено у діаграмі (рис. 3).

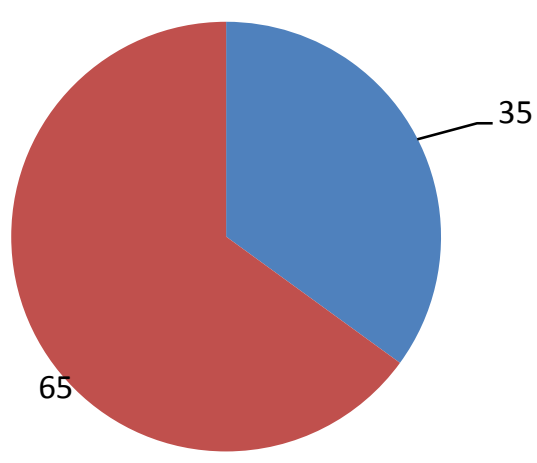

високий рівень

передній рівень

\section{Рис. 3. Рівень егоцентричного спрямування у період ранньої юності}

Як засвідчують результати діагностичного дослідження, студенти періоду ранньої юності проявляють середній (65\%) та високий рівень (35\%) егоцентричної спрямованості. Дані результати засвідчують, що егоцентризм не зникає у ранній юності, а носить досить

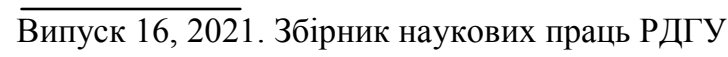


істотну характерологічну особливість. В юнацькому віці на перший план виступає індивідуалізм, власне Его, юнак прагне дослідити власну особистість, самореалізуватися, тому егоцентризм закономірно збільшується. Особи з високим рівнем егоцентризму часто бувають конфліктними, так як не намагаються зрозуміти, а часом і спотворюють смисловий зміст повідомлення співрозмовника, що веде до недовіри і міжособистісних проблем.

У моральному плані егоцентрична спрямованість може вести до егоїзму, який проявляється в спробах використовувати інших людей для задоволення власних потреб та інтересів, а також до прагматизму, тобто зв 'язування всього, з чим індивід зустрічається в житті, тільки зі своєю користю. Факторами, що сприяють розвитку егоцентризму у юнацькому віці, можуть бути: захвалювання батьками чи викладачами, активна стимуляція до досягнення успіху, недолік контактів з однолітками, звички командувати в силу постійного з дитячих років положення керівника (староста, відповідальний за культмасову або спортивну роботу i т.п.). У окремих випадках високий рівень егоцентричної спрямованості може бути ситуативним, викликаним дуже значущою для людини подією,

Висновки 3 даного дослідження і перспективи подальших розвідок. У результаті дослідження, ми підтвердили позицію Фрідмана, який спростував гіпотезу Піаже про те, що до початку підліткового віку егоцентризм зникає (Пашукова, 2005, с. 25). 3 огляду на це можна припустити, що вирішальним фактором у формуванні і проявах егоцентризму буде не стільки розумовий розвиток, скільки соціально- психологічні умови існування індивіда. Це визначає егоцентризм, в деякому сенсі, як захисну реакцію на негативні умови існування; як показник особистісної незрілості індивіда. Він може сприяти порушенню міжособистісних стосунків у період ранньої юності, виникненню психологічних бар'єрів у спілкуванні, зокрема, пов'язаних з низьким рівнем довіри та емпатії.

Подальші перспективи досліджень в цьому напрямку ми бачимо у вивченні детермінант, які впливають на рівень вираженості егоцентричної спрямованості; розробці соціально-психологічного тренінгу, як ефективного засобу підвищення рівня довіри студентів та подолання «егоцентричної сліпоти», пошук ефективніших методів іiї корекції у період ранньої юності.

\section{СПИСОК ПОСИЛАНЬ}

Анненкова, Н. В. (2004). Динамика соотномения подросткового эгоцентризма $и$ становления идентичности. (Дис. канд. психол. наук). Москва.

Антоненко, И. В. (2004). Доверие: социально-психологический феномен. Москва: Социум.

Диагностика уровня эмпатических способностей. Методика В. В. Бойко. Взято с https://pcenter.kiev.ua/test/empaticheskikh-sposobnostey/.

Ефремкина, И. Н. (2019). Исследование особенностей социально-психологических характеристик у лиц юношеского возраста с различным уровнем доверия в межличностных отношениях. Вестник университета, 6, 191-197.

Пашукова, Т. И. (2001). Эгоиентризм: феноменология, закономерности формирования $u$ коррекции. Кировоград: Центр.-укр. изд-во.

Психологические исследования. Практикум по общей психологии для студентов педагогических вузов. (1996). Москва-Воронеж.

Тест Шкала доверия М. Розенберга. Методика Вера в людей. Экспресс-диагностика. Взято с https://psycabi.net/testy/446-test-shkala-doveriya-m-rozenberga-metodika-vera-v-lyudejekspress-diagnostika.

\section{REFERENCES}

Annenkova, N. V. (2004). Dinamika sootnosheniya podrostkovogo egotsentryzma i stanovneniya identychnosti [The dynamics of the relationship between adolescent egocentrism and the formation of identity]. (Dis. kand. psyhol. nauk). Москва. [in Russian].

Antonenko, I. V. (2004). Doveriye: sotsialno-psikhologicheskiy fenomen [Trust: asociopsychological phenomenon]. Moskva: Sotsium. [in Russian]. 
Diagnostika urovnya empaticheskikh sposobnostey. Metodika V. V. Boyko [Diagnostics of the level of empathic abilities. V. V. Boyko]. Vzyato z https://pcenter.kiev.ua/test/empaticheskikhsposobnostey/. [in Russian].

Efremkina, I. N. (2019). Issledovaniye osobennostey sotsialno-psikhologicheskikh kharakteristik u lits yunosheskogo vozrasta $\mathrm{s}$ razlichnym urovnem doveriya $\mathrm{v}$ mezhlichnostnykh otnosheniyakh [A survey of the peculiarities of socio-psychological characteristics of adolescents with different levels of trust in interpersonal relationships]. Vestnik universiteta, 6, 191-197. [in Russian].

Pashukova, T. I. (2001). Egotsentrizm: fenomenologiya, zakonomernosti formirovaniya i korektsiyi [Egocentrism: phenomenology, patterns of formation and correction]. Kirovograd: Tsentr.Ukr. Izd-vo. [in Russian].

Psyhologycheskiye issledovaniya. Praktikum po obshchei psykhologiyi dlastudentov pedagogycheskikh vuzov [Psychological research. Practical work on general psychology for students of pedagogical universities. (1996). Moskva.-Voronezh. [in Russian].

Test Shkala doveriya M. Rozenberga. Metodika Vera v lyudey. Ekspress diagnostika [Test Scale of confidence by M. Rosenberg. Method Faith in people. Express diagnostics]. Vzyato z https://psycabi.net/testy/446-test-shkala-doveriya-m-rozenberga-metodika-vera-v-lyudejekspress-diagnostika. [in Russian].

\title{
EGOCENTRISM AS A FACTOR OF LOW LEVEL OF TRUST IN THE CONTEXT OF INTERPERSONAL RELATIONSHIPS IN LATE ADOLESCENCE
}

Olena Biletska

$\mathrm{PhD}$ student at the Department of Developmental and Pedagogical Psychology, A teacher of Sarny Teachers' Training College Rivne State University of the Humanities https://orcid.org/0000-0002-9447-4455

DOI https://doi.org/10.35619/praprv.v1i16.210

\begin{abstract}
The article is devoted to the theoretical discourse and empirical consideration of the problem of egocentrism which causes a low level of trust in adolescents. The egocentric orientation is determined by the position and contributes to the autonomy of the individual from other people. It is caused by the need of the own success, compassion, care, affiliation, selfaffirmation, protection of one's "I". Egocentrism affects interpersonal relationships, prevents effective communication and interaction with people, puts back the development of the moral and ethical sphere of the individual. Regulation of social behavior and life of the individual directly depends on the characteristics of person's interaction with other people. The personal factor appears in all types of human relationships with each other and interpersonal relationships play a particularly important role.

Based on the results of the diagnosis, the vast majority of people (92\%) with a low level of trust in interpersonal relationships were identified, in which such socio-psychological characteristics as the level of egocentrism and the level of empathic abilities were studied. The results of empirical research indicate excessive concentration of young boys and girls on themselves and their own thoughts, experiences, inability to adequately perceive another participant in the interaction, which is demonstrated in a lack of compassion for the interlocutor, lack of coordination with a partner. The obtained results became a psychological basis for the development of socio-psychological training as an effective means of increasing students' trust and overcoming "egocentric blindness" in early adolescence.
\end{abstract}

Key words: early adolescence, interpersonal relationships, trusting relationships, trust, empathy, egocentrism. 